\title{
NEW EXODUS AND NO EXODUS IN JEREMIAH 26-45

\author{
PROMISE AND WARNING TO THE EXILES IN BABYLON
}

\author{
Gary Yates
}

\begin{abstract}
Summary
Seeking to contribute to the discussion of the book of Jeremiah as a literary unity, this study examines the contrast between the promise of new exodus in Jeremiah 30-33 and the experience of the remnant in Judah after the fall of Jerusalem that is recounted in Jeremiah 40-43 as a reversal of the exodus. This contrast of 'new exodus' and 'no exodus' serves as both a promise and warning to the exilic community in Babylon - the promise that they are to be the recipients of the blessings of restoration and a warning that continued disobedience to YHWH will bring further judgement.
\end{abstract}

\section{Introduction}

R. R. Wilson comments, 'From the standpoint of literary analysis, the book of Jeremiah presents some of the most frustrating problems to be found anywhere.' ${ }^{1}$ More directly, Carroll has observed: 'The person who is not confused by reading the book of Jeremiah has not understood it!' 2 These problems are pronounced in Jeremiah 26-45, the largely narrative section of the book recounting various episodes from the life and ministry of the prophet Jeremiah. Commenting on this

1 Robert R. Wilson, 'Poetry and Prose in the Book of Jeremiah' in Ki Baruch Hu: Ancient Near Eastern, Biblical and Judaic Studies in Honor of Baruch A. Levine, ed. Robert Chazan et al. (Winona Lake, Indiana: Eisenbrauns, 1999): 413.

2 Robert P. Carroll, Jeremiah (OTG; Sheffield: JSOT Press, 1989): 9. 
section of the book, Carroll states, 'No central theme can be detected in the twenty chapters which would allow them a unifying title.' 3

Several features contribute to the apparent literary disarray of Jeremiah 26-45. With the exception of the continuous narrative in chapters 37-43, episodes and messages from the time periods of the reign of Jehoiakim (605-697 BC), the reign of Zedekiah (597-586 BC), and the immediate aftermath of the fall of Jerusalem (post-586 BC) are interspersed with little or no regard for chronological sequence. The poetic oracles in Jeremiah 30-31 seem out of place in a section of the book that otherwise consists exclusively of prose narratives and sermons. Additionally, the message of hope in the so-called 'Book of Consolation' in chapters 30-33 conflicts with the largely negative emphasis on doom and destruction that predominates in the surrounding context. Hobbs writes, 'The reason for the present context of 30-33 still remains something of a mystery.' 4 Similarly, Rofé states that the structure of Jeremiah $25-36$ is 'disturbed by the inclusion of the material in chapters 30,31 , and $33^{\prime} .5$

These difficulties, as well as similar problems of literary cohesion in other portions of the book, appear to suggest a long and complex compositional history for the book of Jeremiah. Other indicators of this complex compositional history would include the textual differences between the Septuagint and Masoretic Text of Jeremiah, the presence of the Jeremiah traditions in various literary forms (poetry/prose; speeches/narrative) and redactional issues related especially to the Deuteronomistic influence on the book. Nevertheless, there is a growing awareness in Jeremiah studies of the evidence of literary and theological unity for the book and a greater scholarly emphasis on synchronic reading of the book of Jeremiah as a literary entity. ${ }^{6}$ The

3 Robert P. Carroll, Jeremiah: A Commentary (OTL; Philadelphia: Westminster, 1986): 509.

4 T. R. Hobbs, 'The Composition and Structure of the Book of Jeremiah', $C B Q 34$ (1972): 268.

5 A. Rofé, 'The Arrangement of the Book of Jeremiah,' ZAW 101 (1991): 395.

6 See J. G. McConville, Judgement and Promise: An Interpretation of the Book of Jeremiah (Winona Lake, Indiana: Eisenbrauns, 1993); Louis Stulman, Order Amid Chaos: Jeremiah as Symbolic Tapestry (The Biblical Seminar 57; Sheffield: Sheffield Academic Press, 1998); Martin Kessler, ed., Reading the Book of Jeremiah: A Search for Coherence (Winona Lake, Indiana: Eisenbrauns, 2004). Recent commentaries on Jeremiah reflecting this shifting emphasis on rhetorical study and/or treatment of Jeremiah as a literary and theological unity include: Louis Stulman, Jeremiah (AOTC; Nashville: Abingdon Press, 2005); Jack R. Lundbom, Jeremiah 1-20: A New Translation with Introduction and Commentary (AB 21A; New York: Doubleday, 1999); Jeremiah 
purpose of this study is to demonstrate that the contrast between Jeremiah's promise of new exodus in Israel's restoration (chs. 30-33) and the story of no exodus (or exodus unravelled) in the experiences of Jeremiah and the Jews remaining in the land following the exile (chs. $40-43$ ) is a central unifying feature in Jeremiah 26-45. ${ }^{7}$ If Jeremiah 2645 were a drama, the plot would revolve around the question of 'What is Israel's future as God's covenant people in light of the fall of Jerusalem, the removal of the Davidic king, and the exile that is narrated in these chapters?' The answer of the Masoretic Text of Jeremiah is that there is hope for Israel's glorious future that lies beyond the bleak experiences of the present. The future lies not with those who remained in the land following the fall of Jerusalem, but with those who will return from exile in Babylon. The rhetorical interplay between chapters $30-33$ and $40-43$ is central to how this message is presented within Jeremiah $26-45$ as a whole.

The contrast between the hope of chapters 30-33 and the doom of chapters 40-43 emphasises the fact that the experiences of the survivors remaining in the land post-586 (chs. 40-43) are the exact opposite of what Jeremiah envisages for Israel in the land at the time of the future restoration and renewal (chs. 30-33). As a result, these contrasts highlight the message of both promise and warning communicated in Jeremiah to the exiles in Babylon. Jeremiah identifies the Babylonian

21-36 (AB 21B; New York: Doubleday, 2004); Jeremiah 37-52 (AB 21C; New York: Doubleday, 2004); Terence E. Fretheim, Jeremiah (Smith and Helwys Bible Commentary; Macon, Georgia: Smith and Helwys, 2002); Walter Brueggemann; A Commentary on Jeremiah: Exile and Homecoming (Grand Rapids: Eerdmans, 1998). For the methodological issues involved in the debate over synchronic and diachronic approaches to the book, see A. R. Pete Diamond, Kathleen M. O'Connor, and Louis Stulman, eds., Troubling Jeremiah (JSOTSup 260; Sheffield: Sheffield Academic Press, 2001).

7 For discussion of the literary structure of Jer. 26-45, see Gary E. Yates, 'Narrative Parallelism and the "Jehoiakim Frame": A Reading Strategy for Jeremiah 26-45', JETS 48 (2005): 263-81. This article argues that chs. 26-45 consists of two panels of material $(26-35,36-45)$ that are framed by passages dating from the time of Jehoiakim (chs. 26, $35,36,45)$. These two panels are also roughly parallel to one another in four ways: (1) Jehoiakim's response of hostile unbelief to the prophetic word $(26,36)$; (2) controversy over Jeremiah's call for submission to Babylon (27-29, 37-39);

(3) messages and events concerning the aftermath of the fall of Jerusalem (30-33, 4043); and (4) the issue of covenant faithfulness with a warning of a message of judgement and a promise of hope to the faithful $(34-35 ; 44-45)$. This structure heightens the contrast between the new exodus in 30-33 and no exodus in 40-43. For a summary of other views concerning the structure of chs. 26-45 (or 21-45), see A. J. O. van der Wal, 'Toward a Synchronic Analysis of MT Jeremiah' in Reading Jeremiah: A Search for Coherence: 13-23. 
exiles as the 'good figs' with whom lay the hopes for Israel's future (24:1-17; contrast 29:17-19). While the promise of restoration stands at a central position in the Masoretic Text of Jeremiah, the book also suggests a potential delay in the realisation of these promises. The exiles must truly repent and avoid the sins of the Jews who remained in the land following the exile if they wish to experience the blessings of restoration.

\section{The Contrast Between New Exodus and No Exodus in Jeremiah 30-33 and 40-43}

\subsection{The Promise of a New Exodus in Jeremiah 30-33}

The central difference between Jeremiah $30-33$ and $40-43$ is the contrasting use of exodus imagery in the two sections. Like other Old Testament prophets, Jeremiah portrays the promised return from Babylonian exile as a new exodus. ${ }^{8}$ Chapters $30-33$ portray a new exodus surpassing the old in magnitude and scope (cf. 23:7-8). On the other hand, chapters 40-43 narrate a sequence of events that constitute a reversal and overturning of the original exodus. Exodus allusions and/or references to the wilderness wanderings and conquest of Canaan during Israel's formative period as a nation are especially prominent in four specific passages in Jeremiah 30-33. In 30:1-4, the restoration and return from exile are specifically linked to the land promise associated

8 Cf. Jer. 50:33-38 and Isa. 4:5-6; 10:26-27; 11:15-16; 35:6-8; 43:1-2, 16-21; 44:27$28 ; 51: 9-11 ; 52: 10-12 ; 55: 12-13$. For the second exodus in the OT prophets, see further Alice Ogden Bellis, 'The New Exodus in Jeremiah 50:33-38' in Imagery and Imagination in Biblical Literature: Essays in Honor of Aloysius Fitzgerald, ed. Lawrence E. Boadt and Mark S. Smith (CBQMS 32; Washington: Catholic Biblical Association, 2001): 157-68; Anthony R. Ceresko, 'The Rhetorical Strategy of the Fourth Servant Song (Isaiah 52:13-53:12): Poetry and the Exodus - New Exodus', CBQ 56 (1994): 42-55; Rikki E. Watts, 'Consolation or Confrontation: Isaiah 40-55 and the Delay of the New Exodus', TynBul 41 (1990): 31-53; Hans M. Barstad, A Way in the Wilderness: The Second Exodus in the Message of 2 Isaiah (JSSM 12; Manchester: University of Manchester Press, 1989); Bernhard W. Anderson, 'Exodus and Covenant in Second Isaiah and Prophetic Tradition' in Magnalia Dei: The Mighty Acts of God: Essays on the Bible and Archaeology in Memory of G. Ernest Wright, ed. Frank M. Cross et al. (Garden City: Doubleday, 1976): 339-60; Dale Patrick, 'Epiphany Imagery in Second Isaiah: Portrayal of a New Exodus', HAR 8 (1984): 125-42. 
with the exodus and the conquest (v. 3). ${ }^{9}$ The fact that $30: 1-4$ serves as the prose introduction to the poetic oracles in chapters 30-31 (and to the message of promise in 30-33 as a whole) signifies the orientation of this entire section toward a presentation of the return from exile as a second exodus.

The oracle of salvation in 31:2-6 is stocked with phrases and imagery associated with the exodus. ${ }^{10}$ Verse 2 provides a summary of the key events in Israel's early salvation history:

1. the exodus ('the people who escaped the sword') 11

2. preservation in the wilderness ('found favour in the wilderness') ${ }^{12}$

3. the conquest ("Israel ... went to find its "rest") $)^{13}$

The reference to 'timbrels' (תף) and 'dancing' (מחול/מהלה) in 31:4 recalls the celebratory song and dance of Miriam in Exodus 15:20-21.14 The motivation behind the deliverance is YHWH's 'everlasting love' for Israel; this sovereign love is presented in the Pentateuch as the basis of YHWH's election of Israel (cf. Deut. 4:37; 5:10; 7:8-9, 13; 10:15; 23:5).

The salvation oracle in Jeremiah 31:31-34 proclaims that the former covenant made under Moses has been broken and that YHWH will establish a new covenant with Israel (cf. 32:38-41). As part of the exodus imagery, Jeremiah himself is portrayed as a new Moses. ${ }^{15}$ Like

9 The phrase אריץ ... נתץ ... ירשי ('the land [God] gave to possess') appears through the book of Deuteronomy in anticipation of the coming conquest (cf. Deut. 3:18; 5:31; $9: 6 ; 15: 4 ; 16: 20 ; 17: 14 ; 19: 2,14 ; 25: 19 ; 26: 1)$.

10 Kenneth Mulzac, 'The Remnant and the New Covenant in the Book of Jeremiah', AUSS 34 (1996): 240-42.

11 Cf. Exod. 5:21; 15:9; 18:4. This expression recalls the exodus as deliverance from death at the hands of Pharaoh and the Egyptian army.

12 Mulzac, 'The Remnant and the New Covenant': 241, n. 11. The phrase 'to find favour' (מצא חן) with YHWH as object is prominent in the book of Exodus (cf. Exod. $33: 12,13[2], 16,17 ; 34: 9$; cf. Num. 11:11;32:5).

13 In 31:2, נרג = 'rest'. The synonymous is used with reference to the exodusconquest (Exod. 33:14; Deut. 12:9, 10; 25:19). See Lundbom, Jeremiah 21-36: 415.

14 A. J. O. van der Wal, 'Themes from Exodus in Jeremiah 30-31' in Studies in the Book of Exodus, ed. Marc Vervenne (Louvain: Peeters, 1996): 563; and Mulzac, 'The Remnant and the New Covenant': 241. Note the recurring theme of joy in 30:19; $31: 13$.

15 For further discussion of this idea of Jeremiah as a new Moses or a prophet like Moses, see William L. Holladay, 'The Background of Jeremiah's Self-Understanding: Moses, Samuel, and Psalm 22', JBL 83 (1964): 153-64; Christopher R. Seitz, 'The Prophet Moses and the Canonical Shape of Jeremiah', ZAW 101 (1991): 3-27; and Dale C. Allison, Jr., The New Moses: A Matthean Typology (Minneapolis: Fortress, 1993): 5262. The prophets Isaiah and Ezekiel are also depicted in ways that show them to be prophets 'like Moses'. See Martin O'Kane, 'Isaiah: A Prophet in the Footsteps of 
Moses at Sinai, Jeremiah functions as a covenant mediator. Holladay explains concerning the Moses imagery applied to the prophet Jeremiah:

Moses had led the Israelites to God's first covenant, and thereby obedience to him and his gift to them of the land became correlated. But now in the eyes of Jeremiah the people had disobeyed, and the land was no longer theirs; and so, as the new Moses in the face of the new wilderness into which the people had been sent, Jeremiah dared to look forward to the time when God would draw up a new covenant, thereby to fulfill his ultimate purposes for his people. ${ }^{16}$

As in the first exodus, the deliverance from exile will be accompanied by the establishment of a covenant between YHWH and Israel, but this 'new' covenant will be qualitatively different from the Sinaitic covenant in that it will guarantee Israel's perpetual fidelity and obedience to its stipulations (cf. 31:31-34; 32:39-41). The future will be radically different in that there will be no need for Israel ever again to experience national judgement. This future act of salvation will secure the relationship between YHWH and Israel intended but never fully realised by the first exodus. ${ }^{17}$

The prayer of the prophet Jeremiah in 32:16-25 also makes an explicit connection between the exodus and Israel's future restoration from exile. Jeremiah 32:1-5 records Jeremiah's purchase of family property at Anathoth, a seemingly foolish act at the time of the Babylonian siege, were it not for YHWH's promise that Israel will regain possession of the land in the future (32:15). Jeremiah's reflection on the creation and exodus traditions gives the prophet confidence that 'nothing is too difficult' for YHWH to accomplish. The prophet's remembrance that YHWH acted with 'a mighty hand and an outstretched arm' in the exodus (32:20-22) leads to faith in YHWH's promise of return and restoration from exile (cf. 32:36-44). ${ }^{18}$

Moses', JSOT 69 (1996): 29-51; and Henry McKeating, 'Ezekiel the "Prophet Like Moses"?' JSOT 69 (1994): 97-109.

16 Holladay, 'The Background of Jeremiah's Self-Understanding': 163.

17 The covenant formulae identifying Israel as the 'people' of YHWH and YHWH as the God of Israel are prominent in Jer. 30-33 and the story of the exodus (cf. 30:22; 31:1, 20; 31:33 and Exod. 6:7; 29:45). See van der Wal, 'Themes From Exodus in Jeremiah 3031': 562-63.

18 Richard D. Patterson and Michael Travers in 'Contours of the Exodus Motif in Jesus' Earthly Ministry', WTJ 66 (2004): 33 note similar prayers of the prophets based on remembrance of the historical exodus in Isa. 63:7-18 and Mic. 7:14-20. 
The remainder of Jeremiah 30-33 fills out the picture of the deliverance from exile as a new exodus. The restoration from exile will provide further demonstration of YHWH's salvific power within the life and history of the people of Israel (cf. 30:7, 10, 11; 31:7-11). ${ }^{19}$ The terms of oppression related to Israel's bondage in Egypt are applied to Judah's slavery in exile. ${ }^{20}$ Like the exodus, the restoration is deliverance from slavery in a foreign land $(30: 8,20)$. The cry of Israel because of its oppression will turn to rejoicing $(31: 9,12-13)$. In the exodus tradition, the deliverance of Israel is the result of YHWH's response to the 'cry' (זעק) of his people (cf. Exod. 2:23; 3:7, 9; 14:10, 15). The root זעי זע that appears in these exodus passages also appears in Jeremiah 30:15, and the reason for Israel's deliverance is that YHWH 'hears' (שממע) the cry of his people and acts on their behalf (31:18; cf. Exod. 3:7). ${ }^{21}$ The cry of Israel because of its oppression will turn to rejoicing $(31: 9,12)$. In both the exodus and the return from exile, YHWH acts as the 'healer' (רפא) of Israel (30:15; Exod. 15:26). ${ }^{22}$

When returning from exile, the people of Israel will plunder their enemies in the same way that their forefathers plundered the Egyptians (30:16; cf. Exod. 12:36), and their foreign oppressors will be destroyed just as the armies of Egypt were defeated at the Sea of Reeds (30:11, 16-17). YHWH will bring fame and renown to himself and to Israel (30:19; 33:8-9). ${ }^{23}$ YHWH will lead his people back to their homeland and will provide water for their journey as in the wilderness $(31: 9,21$; cf. Exod. 14:19; 17:1-7; Num. 20:1-3). The result of this new exodus is

19 Jer. 30-33 employs the same salvific terms used in the exodus tradition to describe the coming restoration: e.g. ישע, 'to save/rescue' (30:7, 10, 11; 31:11; cf. Exod. 14:30; nominal form in Exod. 14:13; 15:2); פדה, 'to ransom/deliver' (31:11; cf. Deut. 7:8; 9:26; 13:6; 15:15; Ps. 78:42; Mic. 6:4; nominal form in Exod. 8:19); גאל, 'to redeem/ deliver' (31:11; cf. Exod. 6:6; 15:13; Pss. 74:2; 77:16; 78:35); and פקד, 'to visit' (30:20; cf. Exod. 3:16; 4:31; 13:19). See van der Wal, 'Themes from Exodus in Jeremiah 3031': 562 .

20 For the exile, Jeremiah uses terms of slavery and oppression associated with the exodus. For the verb עבד ('to serve') in 30:8, note the use of the root in verbal (Exod. $1: 14 ; 5: 18 ; 6: 5$ ) and nominal (Exod. $1: 14 ; 2: 2,23 ; 5: 9,11 ; 6: 6,9)$ form. Note also in Jer. 30:8-9 the transfer from 'service' to foreign oppressor to 'service' to YHWH. The exodus tradition stresses that the outcome of release from Egyptian bondage will be 'service' to YHWH (cf. Exod. 3:12; 4:23; 7:16, 26; 8:1; 9:1, 13, etc.). Other terms of oppression connected to the exodus are מכזב ('sorrow', 30:15; cf. Exod. 3:7) and (to oppress', 30:20; cf. Exod. 3:9). See van der Wal, 'Themes from Exodus': 561.

21 Van der Wal, 'Themes from Exodus': 562.

22 Van der Wal, 'Themes from Exodus': 564.

23 Concern for the divine reputation of YHWH served as an important motivation for the original deliverance of Israel (cf. Exod. 15:14-16; Num. 14:13-17). 
the processional call, 'Come, let us go up to Zion' (31:6) and the joyful streaming of the people of Israel to Zion from the 'ends of the earth' $(31: 8-12) .{ }^{24}$

\subsection{The Problem of No Exodus in Jeremiah 40-43}

The contrast in Jeremiah 40-43 is that the assassination of Gedaliah in 41:1-3 sets in motion a disastrous series of events that leads to the overturning of the first exodus for the remnant living in the land rather than the experience of new exodus promised in chapters 30-33. The Moses imagery associated with Jeremiah in the first panel resumes in Jeremiah 42. Johanan and the Jews under his leadership come seeking intercession and counsel from Jeremiah (cf. 42:1-43:7). The encounter between the people and prophet in chapter 42 resembles another Mount Sinai. Like Moses, Jeremiah 'declares' (נגד) the word of YHWH to the people (42:3-4; cf. Exod. 19:3; Deut. 5:5). The pledge of obedience to the prophetic word on the part of Johanan and his followers who seek guidance from Jeremiah (42:2-6) recalls the ineffectual promise of the people of Israel to obey the terms of YHWH's covenant at Mount Sinai as Moses prepares to go up the mountain to receive the law of God (cf. Exod. 19:8; 24:3, 7). ${ }^{25}$ The almost immediate rejection of following a course of fidelity to YHWH on the part of Johanan and his compatriots (cf. 43:2-7) is further reminiscent of Israel's defection at Sinai in worshipping the golden calf before Moses (cf. Exod. 32). ${ }^{26}$

The descent of Johanan and the small contingent of Jewish refugees (including Jeremiah who is taken against his will) into Egypt out of fear of Babylonian reprisal for the assassination of Gedaliah in 43:2-7 might at first recall Jacob's family going down to Egypt when they were small in number prior to the exodus (cf. Exod. 1:7, 20; Deut. 26:5). ${ }^{27}$ However, this journey down to Egypt in defiance of the prophetic word

24 For development of this processional motif in relationship to the return from exile, see Eugene H. Merrill, 'Pilgrimage and Procession: Motifs of Israel's Return' in Israel's Apostasy and Restoration: Essays in Honor of Roland K. Harrison, ed. A. Gileadi (Grand Rapids: Baker, 1988): 261-72.

25 Lundbom, Jeremiah 37-52: 130. The people of Israel offer similar pledges of fidelity at other times of covenant renewal in the nation's history (cf. Josh. 24:21, 24; 1 Sam. 7:4, $6,8 ; 12: 19)$.

26 The defection of Johanan and his party after ten days (Jer. 42:7) perhaps suggests that Jeremiah's audience had even less resolve than did the contemporaries of Moses who rebelled against YHWH after forty days (cf. Deut. 10:22; 26:5).

27 Lundbom, Jeremiah 37-52: 130. 
ultimately represents a full reversal of the original exodus. ${ }^{28}$ Israel's salvation history has come full circle, and the ultimate covenant curse of return to Egypt has come into effect. Stulman comments that the book of Jeremiah 'presents the end of Israel's story where it originated, back in Egypt'. ${ }^{29}$ The resumption of Jeremiah's ministry of intercession (42:3-4) has raised the possibility that this second Moses would lead Israel to a life of blessing in the promised land, but Jeremiah ultimately fails just like Moses. As in the ministry of Moses, blessing is denied the present generation and transferred to a coming one. ${ }^{30}$ Also, like Moses, Jeremiah identifies so completely with his people in his role as prophet that he too must experience exclusion from the promised land because of the sins of the nation $(43: 6$; cf. Deut. $1: 37 ; 3: 26 ; 4: 21) .{ }^{31}$

\subsection{The Future King in Jeremiah 30-33 and Continued Davidic Failure in Jeremiah 40-43}

The role of the house of David is another specific point of contrast between chapters 30-33 and 40-43. The Book of Consolation looks forward to the coming of the ideal Davidic ruler, the 'righteous Branch' (צמח צדקה) who will bring justice and peace to Jerusalem (33:15-16; cf. 30:9). This Davidic ruler will have a special relationship with YHWH and will 'arise' in order to 'be near' YHWH (30:21). The closing promise in 30-33 is that YHWH's covenant with the house of David is as permanent and abiding as the day and night (33:21-25). ${ }^{32}$

28 Lundbom, Jeremiah 37-52: 130, 134 notes that Israel was not to return to Egypt and that such a return was a direct covenant curse (Deut. 17:16; 28:68; cf. Hos. 8:13). The desire of Johanan's party to go down to Egypt is further 'an echo of the cry' of the unbelieving wilderness generation (cf. Exod. 16:2-3; Num. 14:2-3). The numerous repetitions of 'Egypt' (מצרים) in Jer. 40-43 demonstrate its rhetorical significance in this section: $41: 18 ; 42: 14,15,16,17,18,19 ; 43: 2,7,11,12[2], 13[2]$. This emphasis carries over into ch. 44 (cf. vv. 1, 8, 12[2], 13, 14, 15, 24, 26[2], 27, 28[2], 30).

29 Stulman, Order Amid Chaos: 93. Robert P. Carroll in 'Jeremiah, Intertextuality and Ideologiekritik', JNSL 22 (1996): 28 understands this motif of exodus reversal and, in fact, the reversal of all of Israel's salvation history to be at work throughout the book of Jeremiah. Carroll describes Jer. 2-44 as 'a variation on the story in Exodus to Kings'. In a similar vein, Richard Elliott Friedman argues that the final form of the Deuteronomic History 'tells the story of Israel from Egypt to Egypt' (cf. 2 Kgs 25:26) in 'From Egypt to Egypt Dtr ${ }^{1}$ and $\mathrm{Dtr}^{2}$, Traditions in Transformation: Turning Points in Biblical Faith, ed. Baruch Halpern and Jon D. Levenson (Winona Lake, Indiana: Eisenbrauns, 1981): 189-92

30 Seitz, 'The Prophet Moses and the Canonical Shape of Jeremiah': 15.

31 Seitz, 'The Prophet Moses and the Canonical Shape of Jeremiah': 15.

32 For the messianic prophecies in the book of Jeremiah, see J. J. M. Roberts, 'The Old Testament's Contribution to Messianic Expectations' The Messiah: Developments in 
On the other hand, the sole Davidic figure in Jeremiah 40-43 is the brutally violent Ishmael who murders Gedaliah and inflicts suffering and death on his own people. Israelite theology celebrated the choice of David's family as YHWH's human vice-regent (cf. 2 Sam. 7; Ps. 78:7072). However, in Jeremiah 40-43, Ishmael the Davidide is the usurper who murders Gedaliah, the divinely legitimised leader at this point in Judah's history (cf. 41:1-3). ${ }^{33}$ Before the murder of Gedaliah, the Judean official Johanan expresses his fear that the death of Gedaliah would result in a negation of the blessings of 'return' (שרוב) (40:12) and 'gathering' (קבץ) (40:15) that the people of Judah had begun to experience, and Ishmael's ruthless action brings these fears to realisation. Ishmael takes captives from among the people of Judah and then removes his captives from the land in the same way that the Babylonians have done (41:10; cf. 30:8-9). Ironically, the very segment of the population of Judah that had avoided deportation from the land of promise by the Babylonians is taken captive by a member of the house of David. Ishmael acts more like a foreign oppressor than a beneficent leader. ${ }^{34}$

The Book of Consolation in panel one looks forward to the reuniting of Israel and Judah as one people. YHWH promises, 'I will restore the fortunes of Judah and Israel and will rebuild them as they were before' (33:7) ${ }^{35}$ In contrast to these promises of the reunification of Israel, the narratives in 40-43 portray Ishmael as stoking the fires of the centurieslong division between the north and south by brutally murdering a

Earliest Judaism and Christianity. The Princeton Symposium on Judaism and Christian Origins, ed. James C. Charlesworth (Minneapolis: Fortress, 1992): 46-48.

33 This divine legitimacy comes from the fact that Gedaliah is appointed by Nebuchadnezzar (cf. 40:5, 7, 11;41:2, 18), and Nebuchadnezzar serves in the role of YHWH's 'servant' $(25: 9 ; 27: 6 ; 43: 10)$.

34 The behaviour of Ishmael compares unfavourably with the graciousness and generosity of Nebuchadnezzar (39:11-12), Nebuzaradan (40:1-6), and Gedaliah (40:912). The people of Judah are better off in the hands of the Babylonians than they are in the hands of a member of the family of David.

35 The references to 'Jacob' and 'Ephraim' in the poetic passages in chs. 30-31 also most likely have reference to the Northern Kingdom (cf. 30:7, 10, 18; 31:4-11, 18-22) and were originally delivered during the reign of Josiah when Josiah was attempting to include the former territory of the Northern Kingdom in his religious reforms (cf. $2 \mathrm{Kgs}$ 23:19-20). For the linking of Jer. 30-31 and the time of Josiah's reforms, see Norbert Lohfink, 'Der junge Jeremiah als Propagandist und Poet: Zum Grundstock von Jer. 3031' in Le Livre de Jérémie: Le Prophète et Son Milieu, les Oracles et leur Transmission, ed. Pierre-Maurice Bogaert (Leuven: University Press, 1981): 351-68; and Martin A. Sweeney, 'Jeremiah 30-31 and King Josiah's Program of National Restoration and Religious Reform’, ZAW 108 (1996): 569-83. 
group of seventy pilgrims from Shechem, Shiloh, and Samaria who have come to worship at Jerusalem (41:4-9). Ishmael is the antithesis of the ideal Davidic ruler promised in chapters 30-33.

\subsection{Divine Enablement to Obey versus Persistent Disobedience}

The Book of Consolation envisions a time when YHWH's new covenant with Israel will produce a nation that is completely obedient to the law of God because the law has been internalised and written on the hearts of the people (31:31-34; cf. 24:7). Divine enablement will overcome human weakness and rebellion. ${ }^{36}$ The point of contrast in Jeremiah 40-43 is that the people of Judah in the land are as disobedient after the fall of Jerusalem as they were before. The blessing envisaged in 30-33 has clearly not arrived because the 'old covenant' conditions that have characterised the history of Israel and Judah remain in effect. The new covenant promise in 31:34 is that there will no longer be a need for one man to teach another because all men will know YHWH 'from the least of them to the greatest' (למקטנם ועד-גדולם), but in the immediate aftermath of exile, the people 'from the least of them to the great' (מקטן ועד־גדול) stand in need of having the word of YHWH mediated through the prophet Jeremiah (42:1-3). ${ }^{37}$ When Johanan and his companions ultimately reject Jeremiah's counsel and go to Egypt in disobedience of the divine directive (cf. 43:7), it confirms that the word of YHWH has not been written on their hearts.

One feature of the narratives in 40-43 that especially highlights the continuation of 'old covenant' conditions in the aftermath of exile is that events involving the remnant in the land after the fall of Jerusalem strikingly parallel events occurring in Judah before the fall of Jerusalem. These parallels, which demonstrate that the Jews remaining in the land continue the sins that brought the judgement of exile, include the following:

1. The two major acts of disobedience in 40-43 - Ishmael's assassination of Gedaliah (41:2-3) and Johanan's flight to Egypt (43:1-7) - represent a

\footnotetext{
36 Jeremiah's message is that the human heart is thoroughly corrupted $(5: 23 ; 17: 1,9)$ so that the people do not have the ability on their own to make things right with the Lord (2:25; 13:23). See Lundbom, Jeremiah 21-36: 468-69.

37 Cf. Jer. 44:12, where all of the Jewish remnant in Egypt 'from the least to the greatest' (מקטן רועד-גדול) will be put to death for their disobedience and rebellion.
} 
continued refusal of Jeremiah's counsel to submit to Babylon that had necessitated the destruction of Jerusalem (38:2-4). ${ }^{38}$

2. Ishmael's murder of Gedaliah with the 'sword' (חרב) (41:2) recalls Jehoiakim's execution of the prophet Uriah with the 'sword' (חרב) in 26:20-23.

3. Ishmael's act of dumping bodies in the 'well' (בור) (21:7) recalls the officials of Judah casting Jeremiah into a 'well' (בור) and leaving him to die (38:6-7).

4. Jeremiah's willingness to pray for Johanan and his followers after the fall of Jerusalem (42:2-4) recalls the prophet's refusal to pray for Zedekiah and the people before the fall (37:2-10; 42:2-4). This contrast makes the disobedience of Johanan even more culpable.

5. Johanan's decision to go down to Egypt as a means of avoiding Babylonian reprisal for the assassination of Gedaliah (42:18; 43:4-7) recalls Zedekiah's misguided policy of turning to Egypt for security and protection against the Babylonian siege (37:2-4, 8-10).

6. The accusation of Johanan and his men that Jeremiah is a traitor who only wants them to remain in the land so that he can hand them over to the Babylonians (43:2-3) recalls the charge of Zedekiah's officials that Jeremiah is causing the people of Judah to defect to the Babylonians and weakening the military effort of continued resistance against the Babylonians (38:2-4). Jeremiah labels the charge of Zedekiah's officials as שקר (37:14), while Johanan's delegation accuses Jeremiah of giving counsel that is שק (43:2).

The Judeans in the land after the fall of Jerusalem are the object of judgement rather than the recipients of blessing because they persist in the sins that necessitated the judgement of exile in the first place. The parallelism of events before and after 586 BC in Jeremiah 26-45 serves to demonstrate that the era of restoration and blessing envisaged in chapters 30-33 is far from reality in the experience of the Jews living in the land immediately following the Babylonian exile.

38 Douglas R. Jones in Jeremiah (NCB; Grand Rapids: Eerdmans, 1992): 474 writes: "The first form of this message ... was: "Submit to the Babylonian invader." King and people would not do this and suffered the consequences. The second form was: "Seek the peace of the land under Gedaliah." The people were disposed to accept this counsel, but thrown by foreign interference. The third form after the death of Gedaliah was: "Stay in Judah; do not flee to Egypt."' See also Walter Brueggemann, 'The Baruch Connection', $J B L 113$ (1994): 410, who notes the 'if-then' parallelism between the call for Zedekiah to surrender to the Babylonians in 37:17-18 and the call of Johanan and his associates to remain in the land in 42:9-17. 


\subsection{The Contrasting Sign Acts in Jeremiah 32:1-15 and 43:9-13}

A final point of direct contrast between Jeremiah 30-33 and 40-43 is the sign acts that appear in 32:1-15 and 43:9-13. These two sign acts are similar to one another in that both provide a message concerning the fate of the Jews in a specific land that will fall under the control of Babylon and these two acts visually reflect the intended contrast between $30-33$ as a message of hope and $40-43$ as a section of judgement. In 32:1-15, Jeremiah purchases family property at Anathoth and then concludes the transaction by having his scribe Baruch place the two copies of the title deed to the property in a clay jar. This action is accompanied by the promise that property will once again be purchased in the land (32:15). As Friebel explains, 'Jeremiah's action was a metonymic expression for the resumption of normal economic, societal, familial, and covenantal activities in the land. 39

On the other hand, the sign act of Jeremiah 43 offers a warning that the land of Egypt will become a place of death and destruction for the Jews living there. Jeremiah's burial of several large stones outside a government building in Taphenes signifies Nebuchadnezzar's future conquest of Egypt and marks Egypt as a place where the victorious Nebuchadnezzar will set up his throne (43:10-11). ${ }^{40}$ The Jewish refugees who have fled to Egypt will soon discover that they are unable to run away from YHWH's punishment and Nebuchadnezzar's sovereignty over the nations.

The sign acts of Jeremiah 32:1-15 and 43:8-13 draw the starkest possible contrast between the glorious destiny of those who will participate in the new exodus and the horrible fate awaiting the Jewish refugees who have fled to Egypt in a reversal of God's original act of deliverance for Israel. In Jeremiah 32, YHWH will 'hand over' Jerusalem to the Babylonian king (נתן ... ביד ... נבוכדראצר) (32:28, $36)$, but the land will be returned to Israel in the restoration (32:37-44). In contrast, YHWH will 'hand over' Hophra, the Egyptian Pharaoh, to

39 Kelvin G. Friebel, Jeremiah's and Ezekiel's Sign Acts: Their Meaning and Function as Nonverbal Communication and Rhetoric (JSOTSup 283; Sheffield: Sheffield Academic Press, 1999): 758.

40 Friebel, Jeremiah's and Ezekiel's Sign Acts: 821. Friebel argues that the buried stones represent a mark of the exact place where the described event will take place. The Babylonian king will set up his throne on this spot. Similarly, John A. Thompson in The Book of Jeremiah (NICOT; Grand Rapids: Eerdmans, 1980): 670 suggests that the stones represent the 'pedestal' for the throne that Nebuchadnezzar will set up after his conquest of Egypt. 
Nebuchadnezzar (נתן ... ביד ... נבוכדראצר) (44:30), and the Jews who are living in Egypt will themselves be destroyed (44:11-14, 26-30).

\section{The New Exodus/No Exodus Contrast and Jeremiah's Message Concerning the Future of Israel}

The final section of this paper will attempt to explain the rhetorical setting and function of the contrast between new exodus and no exodus that appears in Jeremiah 30-33 and 40-43. This contrast in Jeremiah is part of the larger concern in the book of Jeremiah to address the issue of Israel's future and which segment of Judah's populace has the blessing of YHWH in the aftermath of exile. As Anderson has explained, the destruction of Jerusalem and the exile to Babylon resulted in a 'heterogeneous constitution of the Jewish people in the Exilic, Postexilic, and Second Temple periods' ${ }^{41}$ Rather than a single people, the Jews in the exilic period existed as three diverse communities: the remnant in Judah, the Jewish refugees who fled to Egypt, and the exiles in Babylon.

\subsection{The Exiles and Israel's Hope for the Future}

The clear intention of the book of Jeremiah is to demonstrate that the hopes for Israel's future restoration as a nation lay with the exiles in Babylon, who appear to have taken the brunt of YHWH's anger. ${ }^{42}$ The exiles are the 'good figs' (24:2-7) and the recipients of YHWH's promise that they will return to the land when the seventy years of exile are over $(24: 5-7 ; 29: 10-14)$. In contrast to these promises to the exiles, Jeremiah places a curse upon every other distinct Jewish group and community: (1) those who remain in the land following the deportation of the exiles in $597 \mathrm{BC}(24: 9 ; 29: 18 ; 34: 17)$; (2) the remnant in the land following

41 Jeff S. Anderson, 'The Metonymical Curse as Propaganda in the Book of Jeremiah', BBR 8 (1998): 7.

42 For this aspect of the message of Jeremiah, see Roy D. Wells, Jr., 'The Amplification of the Expectations of the Exiles in the MT Revision of Jeremiah' in Troubling Jeremiah: 272-92; Robert P. Carroll, 'The Myth of the Empty Land', Semeia 59 (1992): 79-92. Christopher R. Seitz, Theology in Conflict: Reactions to the Exile in the Book of Jeremiah (BZAW 176; Berlin: Walter de Gruyter, 1989): 203-96; and Karl-F. Pohlman, Studien zum Jeremiabuch: Eine Beitrag zur Frage nach der Entstehung des Jeremiabuches (FRLANT 118; Göttingen: Vandenhoeck und Ruprecht, 1978): 183-225. 
the destruction of Jerusalem in $586 \mathrm{BC}(42: 18)$; and (3) the refugees who flee to Egypt after the assassination of Gedaliah $(44: 8,12) .{ }^{43}$

Consistent with this language of cursing, the narratives and messages in Jeremiah portray and/or predict in hyperbolic fashion the destruction of 'all' of Judah with the exception of the exiles in Babylon. ${ }^{44}$ The Jews who remain in the land following the deportation of $597 \mathrm{BC}$ are spoiled and rotten fruit not worthy of preservation (24:2-3, 8-10). This community will be destroyed by the Babylonian assault on Jerusalem because of its covenant infidelity under the leadership of Zedekiah. References to king, leaders, officials, priests, and 'all the people' (34:8, $19-20 ; 35: 17 ; 37: 1-2)$ stress the totality of disobedience and the completeness of the impending judgement. The only group spared from this national destruction is the obscure Rechabite tribe (35:1-16, 18-19), whose continued existence contributes nothing to Israel's future identity as a nation.

According to the book of Jeremiah, the only people left in the land after the fall of Jerusalem in $586 \mathrm{BC}$ are the 'poorest people of the land' (Jer. 39:10; 52:15-16; cf. $2 \mathrm{Kgs} 24: 14 ; 25: 12$ ), and this group also falls under a sentence of total judgement. The impression in Jeremiah is that Johanan's followers who flee to Egypt following the assassination of Gedaliah include all the people of Judah living in the land at that time (note the repetition of 'all' (כל) in 41:16; 42:1 [2], 8 [2], 17; 43:2; 4 [2], 5 [2], 6 and the additional 'from the least of them to the greatest' in $42: 1,8) .{ }^{45}$ When Johanan and his followers disregard the counsel of

43 Anderson, 'The Metonymical Curse as Polemic in the Book of Jeremiah': 5-13. Anderson notes that through these curses 'both Judah and Egypt become the lands of the curse. By the simple process of elimination, it is only the Babylonian community that is left to be the exclusive possessor of hope for a future restoration of Israel' (p. 11). Anderson observes the use of metonymy in the curses against the Jews in Judah and Egypt, where these groups are not only placed under a curse but actually become a curse incarnate $(24: 9 ; 26: 6 ; 29: 18 ; 42: 18 ; 44: 8,12[2] ; 49: 13)$, thus intensifying their condemnation and judgement.

44 For this emphasis on 'all' in Jeremiah's oracles of judgement against the Jews other than the exiles in Babylon, see Fretheim, Jeremiah: 556. Iain Provan, V. Philips Long, and Tremper Longman III in A Biblical History of Israel (Louisville: WJK, 2003): 383, n. 20 observe, “"All” is often used very loosely in the OT (cf. Josh. 10:40-42; 2 Kgs 11:12)'.

45 In 'The Amplification of the Expectations of the Exiles': 279-84, Wells calls attention to how the MT additions in Jer. 40-42 further highlight the idea that all Judeans other than the exiles in Babylon belong to the 'remnant of the land' that falls under YHWH's judgement. The MT plus in Jer. 40:12 (compare Jer. LXX 47:12) reads: 'then all the Judeans returned from all the places to which they had been scattered', indicating that according to the MT, 'the community under Gedaliah and Johanan appears to include 
Jeremiah to remain in the land and choose instead to flee to Egypt, they bring upon themselves a sentence of destruction $(42: 17,18)$. The community remaining in the land post-586 cannot be the recipients of the promise because, from the perspective of Jeremiah, there is no one left in the land once Johanan and his followers depart. ${ }^{46}$

In line with the warning of the complete annihilation of the Jewish refugees in Egypt in 42:18-22, the judgement speech against the Jews in Egypt in Jeremiah 44 further stresses that the judgement will fall upon 'all' (כל) of the people belonging to this segment of the Jewish populace. The entire community is guilty of worshipping other gods - it involves 'all' the Jews living in Lower and Upper Egypt (v. 15) and includes both the men and women (cf. vv. 15, 19, 25). With a unanimous voice, this community expresses blatant rebellion against YHWH: 'We will not obey the message you have spoken to us in the name of YHWH' (v. 16). ${ }^{47}$ They vow as one to carry out their promise to present offerings to the Queen of Heaven (v. 17). Reflecting their

every "scattered" (נדה) Judean not "exiled" to Babylon'. Additions in Jer. MT 41:10-17 (contrast Jer. LXX 48:10-17) suggest that the hostages taken by Ishmael at Mizpah include 'all the remnant of the people' (as opposed to 'all the people who were left at Mizpah' in the LXX) and that this entire remnant becomes the followers of Johanan who go down to Egypt. The plus in Jer. MT 41:14 reads: 'So all the people whom Ishmael had carried away captive from Mizpah turned around and came back, and went to Johanan son of Kareah ...'

46 This portrayal of Judah as an 'empty land' has led to controversy over the historicity of the biblical accounts of the exile and return. The extreme minimalist position is that the exile and return depicted in the OT is a fictional reconstruction of the Persian or Hellenistic period. See Robert P. Carroll, 'Exile! What Exile? Deportation and the Discourses of Diaspora' in Leading Captivity Captive: "The Exile" as History and Ideology, ed. Lester L. Grabbe (JSOTSup 278; Sheffield: Sheffield Academic Press, 1998): 62-79. For a more moderating position, see Hans M. Barstad, The Myth of the Empty Land: A Study in the History and Archaeology of Judah during the 'Exilic' Period (Symbolae isloenses 28; Oslo: Scandanavian University Press, 1996). For a defence of the more traditional view of the exile and return, see Lisbeth S. Fried, 'The Land Lay Desolate: Conquest and Restoration in the Ancient Near East' in Judah and the Judeans in the Neo-Babylonian Period, ed. Oded Lipschits and Joseph Blenkinsopp (Winona Lake, Indiana: Eisenbrauns, 2003): 21-54; and Bustenay Oded, 'Where is the "Myth of the Empty Land" To Be Found? History versus Myth' in Judah and the Judeans in the Neo-Babylonian Period: 55-74.

47 The chronological narrative of Jer. $37-44$ is framed by references to 'not hearing' (לא שמע) the word of the Lord (cf. 37:1-2; 44:16, 23), once again linking the sins of Judah before and after the fall of Jerusalem. See Stulman, Order Amid Chaos: 90. Stulman notes that the verb שמע appears 34 times in Jer. 36-45, demonstrating the centrality of the issue of response to the word of YHWH in this section. The overarching theme of Jer. 26-45 is that Judah 'has not listened to/obeyed' the word of YHWH (cf. $26: 5 ; 29: 19 ; 32: 33 ; 34: 14,17 ; 35: 14,15,16,17 ; 36: 31 ; 37: 14 ; 40: 3 ; 42: 13,21 ; 43: 7$; $44: 16.23)$. 
total disregard for the covenant with YHWH, they attribute the fall of Jerusalem to the Josianic reforms that brought an end to the idolatrous practices that were common during the reigns of Manasseh and Amon (v. 18; cf. 2 Kgs 21:2-9, 20-22), believing that the gods have withheld their blessing. ${ }^{48}$

The defiant rebellion of the Jewish community in Egypt brings the deserved sentence of complete destruction. Jeremiah's announcements of judgement in vv. 20-29 are directed to 'all' (כל) of the Jews in Egypt (vv. 20, 24, 26 - note also 'all' in vv. 12, 28 and 'from the least to the greatest' in v. 12). There will be no survivors of the 'sword and famine' among them (vv. 12-13, 27). ${ }^{49}$ The 'remnant' in Egypt who has survived the destruction of Jerusalem will not themselves leave behind a 'remnant' (vv. 7, 14). ${ }^{50}$

\subsection{The Warning to the Exiles}

In one sense, the message of Jeremiah could be viewed as political 'propaganda' written to support the favoured status of one Jewish community over its rivals. Carroll argues that the perspective of the book of Jeremiah concerning the fate of the Jewish communities after the fall of Jerusalem:

reflects an ideology of occupation and control of the temple community in the reconstructionist era of the Persian period. Not only are there exclusivistic claims to possession of and power in the land, but there is also such a denigration of all opposition that no rival claim has any legitimacy whatsoever. Where once deportation may have been a sign of divine anger and rejection, here it has become a foundational element in the warrants for empowerment in the land (cf. Ezek. 11:14-21). ${ }^{51}$

48 Holladay, Jeremiah 2: 304. For further explanation of this distorted view of Israel's covenant history, see David Noel Freedman, ‘A Biblical Idea of History', Int 21 (1967): 33-37.

49 The hyperbolic nature of these statements is clearly demonstrated by the references to the 'few survivors' in v. 14 and those who 'escape the sword' and return to the promised land in v. 28.

50 The repeated use of the term 'remnant' (שארית) for the Jews remaining in the land and/or going down to Egypt after the fall of Jerusalem (cf. 40:11, 15; 41:10, 16; 42:2, 15, $19 ; 44: 12,14,28)$ is tinged with irony. These people are a 'remnant' of survivors but not the 'remnant' that will experience YHWH's ultimate salvation.

51 Carroll, 'The Myth of the Empty Land', 83. Anderson ('The Metonymical Curse as Propaganda': 10) argues that the hyperbolic portrayal of no one left in the land after Johanan and his followers depart for Egypt in 43:1-7 is 'self-serving ideological propaganda pointing to the vested interests of the Babylonian community'. Wells ('The Amplification of the Expectation of the Exiles': 292) also writes: 'The privilege of the Babylonian exiles consists of a final elimination of all claimants to a future in the land.' 
And yet, the message of Jeremiah is much more than an assertion of the favoured status of the Babylonian exiles. The rhetorical interplay of Jeremiah 30-33 and 40-43 and the contrast between new exodus and no exodus serves as both a promise and a warning for the exiles. Positively, the narrative accounts in 40-43 would demonstrate that removal from the promised land did not cause the exiles to miss out on the blessings of restoration and new exodus. Conditions in Judah in the immediate aftermath of the exile ultimately turned out to be the exact opposite of what Jeremiah envisaged for Israel's future restoration and renewal. The Jews left in the land had no advantage over the exiles and they did not remain in the land because they were exempt from God's judgement.

Negatively, the narrative of Jeremiah 40-43 and what happened to the Jews remaining in the land who later fled to Egypt, would serve as a warning to the exiles of what would happen to them if they continued the rebellious behaviour that had characterised Judah's past. As Ben Zvi has observed, the prophetic books of the Hebrew Bible often reflect a 'past fulfilment perspective', in which historical events have proven the accuracy of the prophet's warnings of judgement and provide a warning to the contemporary audience to whom the book is addressed; subsequent generations that persistence in unbelief and disobedience will bring further judgement from God. ${ }^{52}$

Seitz's assessment that the book of Jeremiah views the exiles in Babylon as 'God's obedient folk' is an oversimplification. ${ }^{53}$ The Jews in Babylon are deserving of their exile because they have not obeyed YHWH (29:19). ${ }^{54}$ Rather than simply being labelled as 'God's obedient folk', the exiles are commanded to obey YHWH's command to 'build houses, settle (רשוטבו), and plant gardens' in submission to Babylonian

52 Ehud Ben Zvi, A Historical-Critical Study of the Book of Obadiah (New York: Walter de Gruyter, 1996): 39. Karl Möller in A Prophet in Debate: The Rhetoric of Persuasion in the Book of Amos (JSOTSup 372; Sheffield: Sheffield Academic, 2002): 119-20 argues for a similar perspective in the book of Amos.

53 Christopher R. Seitz, 'The Crisis of Interpretation Over the Meaning and Purpose of the Exile: A redactional study of Jeremiah xxi-xliii', VT 35 (1985): 94.

54 The only Babylonian exiles mentioned by name in the book of Jeremiah (other than the kings Jehoiachin and Zedekiah) are the wicked trio of false prophets - Ahab, Zedekiah, and Shemaiah - who seek to convince their fellow-exiles that their stay in Babylon will not be long-lasting, as Jeremiah had warned (cf. 29:20-23, 24-32). Shemaiah and his descendants will never see the future salvation that YHWH has planned for his people (29:32), and this same warning would appear to apply to any of the exiles who follow the deluded message of these false prophets (cf. 29:16-19). 
authority over their lives (29:4-7). The issue of how the exiles respond to this prophetic call for submission to Babylon is precisely why the story of what happened to the remnant in the land is so important. Like the exiles, the remnant in the land had a real opportunity to experience divine blessing. Gedaliah promised the people in the land that things would go well for them if they would 'settle' (שבו) in the land and serve the Babylonians (40:9). ${ }^{55}$ Jews scattered to the lands surrounding Judah had 'returned' (שרוב) to join Gedaliah in the homeland (40:12).56 The remnant in the land also enjoyed a productive harvest while Gedaliah was their governor (40:12) ${ }^{57}$ As Lundbom observes, 'It seems as if Jeremiah's words about people returning to the land are being wonderfully fulfilled.' 58 The death of Gedaliah serves to shatter the prophet's hopes. ${ }^{59}$

Even after the death of Gedaliah, Jeremiah prays for the remnant in the land because the divine prohibition of prophetic intercession, in effect, before the exile has been removed (42:2-4; cf. 7:16; 11:14; 14:11). The remnant gives their solemn promise to 'obey' (שמע) the Lord (42:6), and Jeremiah promises that obedience to his counsel to remain in the land will result in blessing rather than disaster (42:10). Just like the exiles in Babylon, the remnant in the land had received a genuine offer of divine blessing, but the potential blessing is forfeited when Johanan and his followers 'disobey' (לא שמע) the word of YHWH and flee to Egypt (43:4-7). ${ }^{60}$

55 Gedaliah's assurance parallels the promises that Israel will 'dwell' (ישבב) in the land in chs. 30-33 (31:24; 32:27; cf. 30:10; 31:40; 33:16).

56 W. McKane, A Critical and Exegetical Commentary on Jeremiah 26-52 (ICC; Edinburgh: T. \& T. Clark, 1996): 1003, notes that the language of dispersal in 40:12 is applied to those given the promise of return in $16: 15 ; 23: 3,8 ; 29: 14 ; 30: 11 ; 32: 37 ; 46: 28$. שוב is the key verb used for this promised restoration in Jer. 30-33 (cf. 30:3, 10, 18, 24; $31: 8,16,17,18,19,21,23 ; 32: 37,40,44 ; 33: 7,11,26$; cf. 29:10, 14).

57 Cf. the promises of agricultural bounty in Jer. 31:5, 12-13.

58 Lundbom, Jeremiah 37-52: 123.

59 McKane, A Critical and Exegetical Commentary on Jeremiah 26-52: 1026. McKane also notes that Ishmael's murder of the pilgrims from the north in 41:5-7 is an important element in the shattering of these hopes because Jer. 3:16 and 31:6 anticipate a reunified Israel worshipping in Jerusalem.

60 Seitz, Theology in Conflict: 273-91 attributes the contrasting offer of hope to the Jews remaining in the land and their judgement for disobedience to two major redactional layers in the Jeremianic tradition. The first is the Scribal Chronicle, probably written by a member of the post-597 community who holds forth the possibility of a 'legitimate existence for a remnant community and king, in the land, after the events of 597 and 587' (p. 286). This perspective reflects the viewpoint of the prophet Jeremiah and is expressed in the messages and oracles originating with the prophet. The second 
In the book of Jeremiah, the Jewish remnant in the land is not so much a rival group to the exiles as a mirror image to help the exiles see for themselves the ultimate consequences of failure to follow the prophetic counsel to settle down and submit to Babylon. Rather than merely using the language of preaching (command and warning), the book of Jeremiah employs the more effective tool of teaching by example. This example has even greater impact in that it focuses on the failure of a rival community that members of the exilic community would have readily acknowledged. If the exiles are willing to admit that the remnant in the land made a mistake in not submitting to Babylon and not obeying the Lord, then they should be wise enough not to follow the same course of action. By dispassionately observing from the 'past fulfilment perspective' what happened to the remnant in the land after the fall of Jerusalem, the exiles could see what the future held for them if they refused to 'settle' in Babylon while waiting for the future restoration. ${ }^{61}$

layer reflects the perspective of the Exilic Redaction, which favours the status of the exilic community, rules out the possibility of any continued existence in the land by focusing on 'the finality of judgement over remnant and king' (p. 286).

While comparison of the LXX and MT of Jeremiah would support the idea of editorial amplification and clarification of the favoured status of the Babylonian exiles over the other Jewish communities in the exilic period (see Wells, 'The Amplification of the Expectations of the Exiles': 272-92 and n. 43 above), one must be careful that this insight does not negate recognition of the fact that the fate of the Jews that remain in the land in the book of Jeremiah is due to their disobedience to the prophetic word (cf. 43:7). Thus, there is nothing unlikely in the conjecture that the prophet Jeremiah offered hope of continued existence in the land for the post-597 and 586 communities (based upon their response to the prophetic word), while recognising that Israel's ultimate hope lay with the restoration of the exiles from Babylon. Seitz divides too sharply between the perspective of the Scribal Chronicle and the Exilic Redactor. Fretheim (Jeremiah: 569) observes that "it is important to say that this "remnant of Judah" [in the land] was not excluded in principle ... The earlier positive portrayals of this group make the point that, for God, they could have been included in the ongoing community of faith in time, joining the exiles in Babylon in some future shape of Israel. They chose a different path and shaped for themselves a different future, but that was their doing, not God's.'

61 Conversely, those individuals who respond with repentance, faith, and obedience to the prophetic message serve as positive examples for the exilic community of the desired response to the prophetic word. These examples include: the elders who defended Jeremiah after his temple sermon (26:17-19); the official Ahikam who protected Jeremiah from execution by the people (26:24); the faithful scribe Baruch (cf. 36:4-9; 45:1-5); the royal officials who hid Jeremiah and counselled Jehoiakim to take seriously the warnings found in the scroll of Jeremiah's prophecies (36:10-26); and the foreigner Ebed-Melech who pleaded to Zedekiah for Jeremiah's life (38:7-13). See Christopher R. Seitz, 'The Place of the Reader in Jeremiah' in Reading Jeremiah: A Search for Coherence: 73. 
More than simply validating the favoured status of the exiles in Babylon, the rhetorical function of the demise of the remnant in the land and the contrast between new exodus/no exodus in Jeremiah 30-33 and $40-43$ is to motivate the exiles to obedience. The exilic community must do more than simply wait out the seventy years in order to become the recipients of restoration. YHWH promises to 'bring back' (שוב) the exiles (29:10), but their return will only come when they 'seek' YHWH with all their heart (29:12-14). When they turn to YHWH in prayer, then YHWH will respond to their cries for help (29:12). ${ }^{62}$

YHWH has promised restoration to the exilic community, but promised blessing can be forfeited by disobedience to YHWH. For the exiles, the remnant in the land functions as an all-too-real demonstration of the theological principle of Jeremiah 18:7-10 - that disobedience can turn promised blessing into judgement and disaster. The fact that the remnant in the land essentially repeats the sins of Judah that had previously necessitated the judgement of 586 BC should further serve as a warning to the exiles of their own systemic corruption and tendency toward disobedience. The message of the Masoretic Text of Jeremiah is that the exile is continuing and 'unended' as long as the exiles persist in their disobedience. ${ }^{63}$ McKane writes that the promissory message of Jeremiah 'is disengaged from a present which offers no support for it and demands nothing less than a new age - a Messianic age'. ${ }^{64}$

The tension between the divine initiative to save and the necessity of human responsiveness toward YHWH found in the theology of Jeremiah means that the promises of restoration in this book have an open-ended quality to them. The promises are certain in terms of their ultimate fulfilment because YHWH will ultimately act unilaterally to bring about Israel's obedience and faithfulness (cf. 31:31-34), but the timing of the fulfilment is unclear. The fact that the disobedience of the remnant in the land is the final chronological event in the ministry of Jeremiah suggests delay in the realisation of Jeremiah's promises of complete restoration for Israel as a nation. There is even the implied warning that

62 Fretheim (Jeremiah: 405) unconvincingly attempts to argue that any emphasis on human conditionality in the response of the exiles to God "would be no "assertion of the gospel"'.

63 For further development of this idea of the 'unended exile' in Jeremiah, see John Hill, "'Your Exile Will Be Long": The Book of Jeremiah and the Unended Exile' in Reading Jeremiah: A Search for Coherence: 149-61.

64 McKane, A Critical and Exegetical Commentary on Jeremiah 26-52: 755. 
the end of the seventy years will not bring automatic blessing and restoration for the exiles.

Even when YHWH promises to act unilaterally to save, human response to the word of YHWH is a determining factor in the timing of the fulfilment of these promises. While Jeremiah promises in 31:31-34 that YHWH will act unilaterally to restore his people, he also proclaims that the people have a responsibility to seek YHWH and to turn to him (cf. 29:10-14). ${ }^{65}$ There is clearly a paradox in this aspect of the prophetic message, but the prophets are unconcerned to resolve the tension between divine enablement and human responsibility in the manner of a systematic theologian. Instead their objective is to call the people to return to YHWH so that the pattern of disobedience that has necessitated YHWH's judgement might be broken.

\section{Conclusion}

The tension between new exodus and no exodus is central to the literary structure of Jeremiah 26-45 and the theological message of the book of Jeremiah as a whole. YHWH will restore his people from exile with a second exodus even greater than the first (Jer. 30-33), but the exodus reversal experienced by the remnant in the land as the final chronological event in the ministry of Jeremiah (Jer. 40-43) suggests that unbelief and disobedience remain as impediments to the blessings of restoration promised to the exilic community. Jeremiah's view of the future is promising, but there is also an element of uncertainty as to when Israel's glorious future will appear. While looking forward to the fulfilment of YHWH's promises of restoration and renewal, the exilic community must also look backward and learn from the experiences of the remnant in the land that missed out on potential blessing because of their disobedience to the word of YHWH.

65 Lundbom (Jeremiah 21-36: 469) notes this same tension in the message of the prophet Ezekiel. YHWH promises to give Israel a new 'heart' and 'spirit' (Ezek. 11:19; $36: 21$ ), but Israel also has a responsibility 'get a new heart and a new spirit' for themselves (Ezek. 18:31). 